\title{
Comparative anatomical study of leaf tissues of scab resistant and susceptible apple cultivars
}

\author{
Varga, D. \& Udvardy, L. \\ Corvinus University of Budapest Faculty of Horticultural Science Department of Botany and Soroksár Botanical \\ Garden Budapest, Villányi út 29-43. laszlo.udvardy@uni-corinus.hu
}

\begin{abstract}
Summary: According to previous studies some anatomical features seem to be connected with resistance or susceptibility to scab caused by Venturia ineaqulis (Cke./Wint.) in case of a given cultivar. Study of leaf anatomy of three scab resistant ('Prima', 'Florina', MR-12) and two susceptible ('Watson Jonathan', 'Golden Delicious Reinders') apple cultivars have been made. Preserved preparations made of leaves has been studied by light microscope. Studied parameters were: thickness of leaf blade, thickness of palisade and spongy parenchyma, thickness of epidermal cells, thickness of the cuticle. By measuring leaf thickness and epidermal cell thickness visible differences appeared in certain cultivars, while most conspicuous difference has been shown in thickness of the cuticle.
\end{abstract}

Key words: scab resistant cultivars, apple, anatomy

\section{Introduction}

According to the studies of Tóth \& Gracza (2005) leaf anatomical investigations has been made on further apple cultivars. The aim of the present study was to recover possible anatomical reason of resistance or susceptibility by exploring anatomical structure of apple leaves.

According to the study of the development of the fungus on living leaf, germinated spores of Venturia inaequalis (CKE.) WINT. are becoming appressorium-like extensions, and then enter through the host's cuticle, grow, and develop into subcuticular stroma. Cells differentiate into a pseudoparenchyma within the stroma, while cuticle encircling the subcuticular hypha thickened significantly in comparison with not infected parts (Kucheryava et al., 2008). After the hypha broke through the epidermis, and feeds on the plant's internal sap, no longer depends on leaf surface moisture (Oberhofer, 1985; Holb, 2002).

Variety of symptoms' intensity or different types of symptoms can be assigned to ontogenetic resistance, susceptibility increasing in the autumn, and the interaction between the given apple genotype and the variable genotype of the pathogen (Gessler et al., 2006). In an open orchard during a four year experiment it has been stated (by Brun et al., 2008), that even in years favourable for infection resistant cultivars have infected only in a few percent, while susceptible cultivars were infected in $100 \%$. Infraspecific diversity is supported by open field observations (Tóth et al., 1998), which can reveals gross in leaf size and shape, pubescence of upper and lower side, glossy and leathery (coriaceous) texture of the leaf. Further observations shown essential differences in anatomical structure of 'Jonathan', 'Starking' and 'Golden Delicious' apple cultivar leaves (Tóth et al., 2004). Our interest has been risen to do further, more detailed anatomical study of leaves by morphological differences observed during introduction and propagation of non-native scab resistant apple cultivars - both in case of scab resistant and susceptible cultivars (Tóth \& Szabó, 2000; Tóth, 2005 ). As a result of detailed investigations (Tóth \& Gracza, 2005), morphological differences of two susceptible ('Jonathan' and 'Idared') and two resistant cultivars ('Florina' and 'Freedom'), and two resistant candidates (MR-10 és MR-11) have been revealed. Essential differences have been appeared in leaf blade thickness, palisade and spongy parenchyma size, leaf pubescence, epidermis cell size and shape, and cross section of the midrib.

\section{Materials and methods}

Two scab susceptible ('Watson Jonathan', 'Golden Reinders'), two resistant ('Florina', 'Prima'), and one candidate apple cultivar (MR-12) bred by the Department of Pomology (Tóth, 2005) has been chosen for investigations. Leaves were obtained from the Soroksár Experimental Station of Corvinus University of Budapest; date of sample taking is $8^{\text {th }}$ August 2009. All investigated cultivars are grafted on M9 rootstocks. In case of all cultivars 15 leaves were picked from separate trees from the half length of a long shoots, leaves were in the same developing stage. Preparation of leaves has been done fresh by freezing microtome, preparations have been studied by light microscope. Measured parameters are: leaf thickness, palisade parenchyma thickness including upper epidermal cells, thickness of spongy parenchyma including lower epidermis, upper and lower epidermis thickness, and cuticle thickness. 


\section{Results}

\section{Thickness of leaf blade}

During measuring leaf cross sections visible differences appeared in leaf blade thickness in certain cultivars. Leaf thickness is lowest of resistant cultivar 'Florina'- $959 \mu \mathrm{m}$ in average. Leaf blades of two scab susceptible cultivars 'Watson Jonathan' and 'Golden Reinders' are much thicker, and near the same: in average 1272 and $1278 \mu \mathrm{m}$, respectively. That of resistant cultivar 'Prima' is $1305 \mu \mathrm{m}$, while the thickest is of resistant candidate cultivar MR-12: in average $1422 \mu \mathrm{m}$.

\section{Palisade and spongy parenchyma}

As it could be expected from leaf blade thickness, palisade and spongy parenchyma is the thinnest in cultivar 'Florina', together with epidermal cells in average they are 602.5 and $372 \mu \mathrm{m}$, respectively. 'Golden Reinders' and 'Watson Jonathan' are similar to one another, palisade parenchima with upper epidermis averages 801 and $811 \mu \mathrm{m}$, and spongy parenchyma with lower epidermis averages 467 and $476 \mu \mathrm{m}$, respectively. In case of cultivar 'Prima' palisade parenchyma is $766 \mu \mathrm{m}$, and spongy parenchyma is $555 \mu \mathrm{m}$ in average. Palisade parenchyma together with epidermis is the thickest in candidate cultivar MR-12: $830 \mu \mathrm{m}$, here spongy parenchyma with epidermis is $607 \mu \mathrm{m}$ thick in average.

Number of palisade parenchyma layers differed from earlier measuring and literature data in studied cultivars. According to the investigations of Tóth \& Gracza (2005) number of palisade parenchyma layers are two in 'Florina', and three in 'Jonathan' and clones MR-10 and MR-11. In contrast, during our latest measuring three layers of palisade parenchyma could be distinguished in 'Florina' leaves, and two layers in all other cultivars, including 'Watson Jonathan' and MR-12. The difference may arise from the possible fact, that leaves collected for the previous investigations may have been in different development stage, or they were collected from a different part of the shoot.
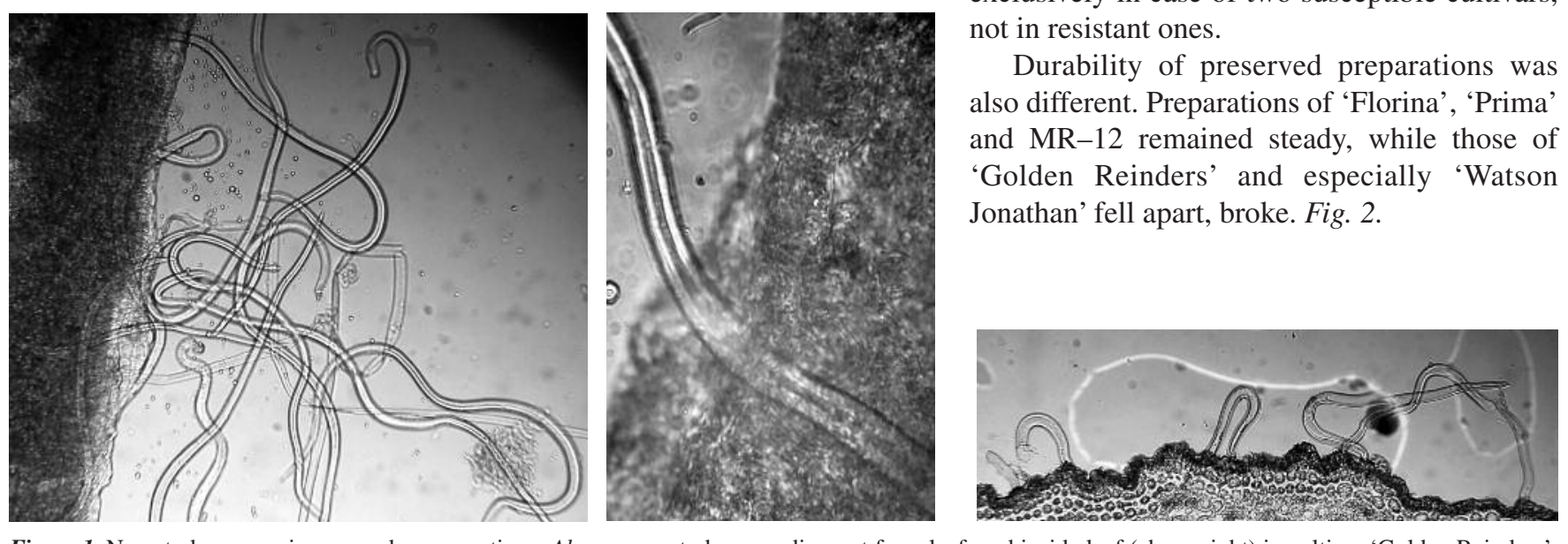

Figure 1. Nematodes appearing around cross sections. Above: nematodes crowding out from leaf, and inside leaf (above right) in cultivar 'Golden Reinders'. Below: Nematodes appearing along the midrib in cultivar 'Watson Jonathan'.

Table 1. Thickness of epidermal cells and cuticle in studied cultivars.

\begin{tabular}{|l|c|c|c|c|}
\hline Cultivar & $\begin{array}{c}\text { Upper } \\
\text { epidermis } \\
\text { (ìm) }\end{array}$ & $\begin{array}{c}\text { Lower } \\
\text { epidermis } \\
\text { (ìm) }\end{array}$ & $\begin{array}{c}\text { Upper } \\
\text { cuticle } \\
\text { (im) }\end{array}$ & $\begin{array}{c}\text { Lower } \\
\text { cuticle } \\
\text { (ìm) }\end{array}$ \\
\hline 'Florina' & 51 & 49.6 & 15.5 & 8.85 \\
\hline 'Prima' & 59.5 & 51.6 & 16 & 12.25 \\
\hline 'MR-12' & 52.5 & 59.25 & 19.5 & 11.75 \\
\hline 'Watson J.' & 61.75 & 55.9 & $\mathbf{7 . 5}$ & $\mathbf{5 . 2 5}$ \\
\hline 'Golden R.' & 69.1 & 67.25 & 17 & 8 \\
\hline
\end{tabular}

\section{Epidermis and cuticle}

Thickness of epidermal cells show a great variability even within one cultivar. Among investigated cultivars the thinnest epidermal cells have been found in 'Florina', slightly thicker in 'Prima', while in candidate cultivar MR-12 lower epidermal cells were thicker than upper ones. Cells of 'Watson Jonathan' and 'Golden Reinders' proved to be the thickest, see Table 1.

Cuticle thickness was extremely fluctuating, from 2.5 to 25 ìm in each cultivar. It can be stated, that upper cuticle is thicker than that of the lower side, in average 15-20 $\mu \mathrm{m}$, except 'Watson Jonathan', where upper cuticle is only 7.5 um Table 1.

If survival of Venturia inaequalis after germination depends on the speed of penetration through the cuticle and of reaching plant tissues, then scab resistance of a cultivar greatly depends on cuticle thickness to all probability.

\section{Unexpected result}

One day after making preserved preparations of leaf cross sections of two scab susceptible cultivars ('Watson Jonathan' and 'Golden Reinders'), dozens of nematodes swam in slides coming from the phloem Fig. 1. Connection between scab susceptibility and presence of nematodes is neither proved, nor excluded. Revealing this needs further investigations. However, presence of nematodes have been observed exclusively in case of two susceptible cultivars, not in resistant ones.

Durability of preserved preparations was also different. Preparations of 'Florina', 'Prima' and MR-12 remained steady, while those of 'Golden Reinders' and especially 'Watson Jonathan' fell apart, broke. Fig. 2. 

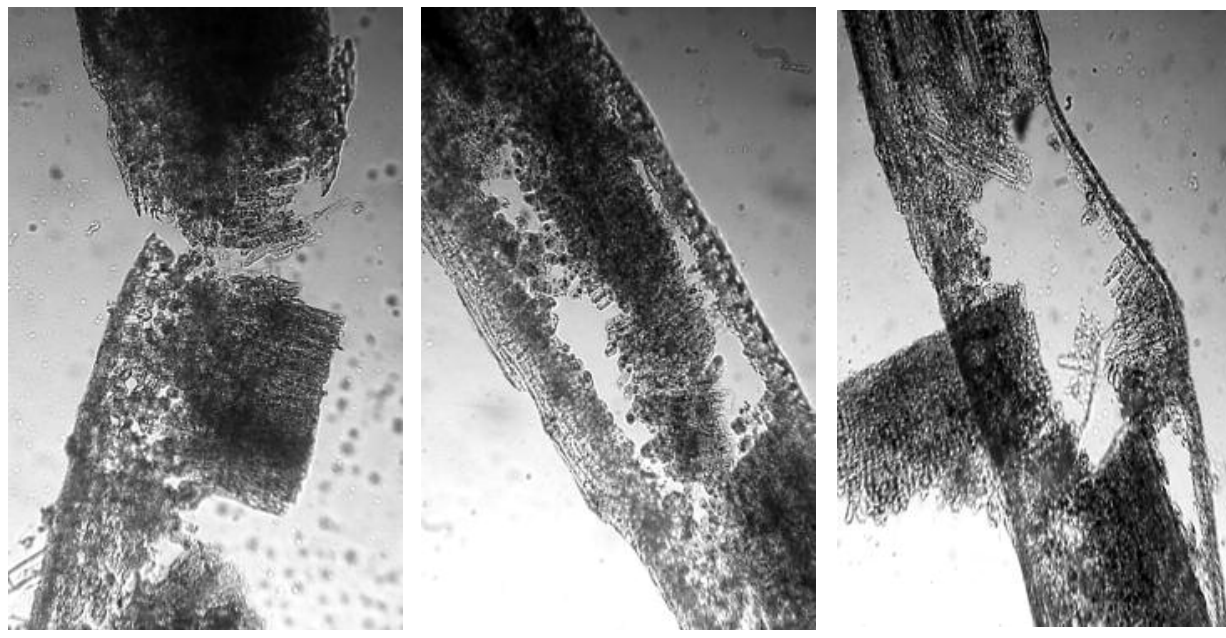

Figure 2. Tissue structure falling apart in cultivar 'Watson Jonathan'. From entirely unbroken preparations leaf blade broke in many parts after $1-2$ weeks.

\section{References}

Brun, L., Didelot, F. \& Parisi, L. (2008): Effects of apple cultivar susceptibility to Venturia inaequalis on scab epidemics in apple orchards. - Crop Protection 27: 1009-1019.

Gessler, C., Patocchi, A., Sansavini, S., Tartarini, S. \& Gianfranceschi, L. (2006): Venturia inaequalis Resistance in Apple. Critical Reviews in Plant Science, 25: 473-503

Holb, I. (2002): A betegség és a kórokozó általános jellemzői. A kórokozó életciklusa. In: Holb I (szerk.) Az alma ventúriás varaso- dása: biológia, elörejelzés és védekezés. Szaktudás Kiadó Ház, Budapest, pp. 13-28

Kucheryava, N., Bowen, J. K., Sutherland, P. W., Conolly, J. J., Mesarich, C. H., Rikkerink, E., Kemen E., Plummer, K. M., Hahn, M. \& Templeton, M. D. (2008): Two novel Venturia inaequalis genes induced upon morphogenetic differentiation during infection and in vitro growth on cellophane. Fungal Genetics and Biology 45: 1329-1339.

Oberhofer, H. (1985): Az almavarasodás biológiája és a védekezés. Új Idő Kft, Budapest. 136 pp.

Tóth, M. (2005): Six promising selections from the Hungarian apple breeding program for multiple resistance, Int. J. of Hort. Sci., 11. (3): 23-28.

Tóth, M. \& Gracza, P. (2005): Anatomical study of the leaves and petioles of scab resistant and susceptible apple cultivars. Int. J. of Hort. Sci., 11. (3): 53-57.

Tóth, M., Gracza, P. \& Simon, G. (2004): Néhány almafajta levelének összehasonlító szöveti viszonyai. 26. Biológiai Vándorgyülés, Budapest. Proceedings: 65-66.

Tóth, M., Kovács, Sz., Quang, Do X. (1998): Some morphological traits of apple offsprings from scab-resistant progenitors, Acta Horticulturae. 484: 285-290. 